\title{
HUBUNGAN MOTIVASI IBU DENGAN DETEKSI DINI KANKER SERVIKS MELALUI METODE INSPEKSI VISUAL ASAM ASETAT (IVA)
}

\section{CORRELATION BETWEEN MOTHER MOTIVATION WITH OF EARLY CERVIX CANCER DETECTION THROUGH INSPECTION OF VISUAL ACID ACETATE (IVA)}

\author{
Weni Lidya Hendayani ${ }^{1}$, Hendrawati ${ }^{2}$ \\ ${ }^{1,2}$ Akademi Keperawatan Nabila Padang Panjang \\ Email : weni.lidya@yahoo.com
}

Naskah Masuk: 30-04-2019

Naskah Diterima: 17-05-2019

Naskah Disetujui: 11-06-2019

\begin{abstract}
Cervix cancer has become women's health problem that should get serious concern. One of the causes of death from cervical cancer is delayed detection. Data WHO in 2010, 500.000 new cases with death 280.000 suffered was happened every year in the world. These supposed to be minimized by primary prevention that is Pap Smear or IVA Test. The purpose of study was to determine mother motivation with of early cervix cancer detection through inspection of visual acid acetate (IVA). This study used cross sectional method. The study was conducted at Work Area Of Kebun Sikolos Comunity Healthy Center in March 2018. The research Sampling is eproductive age of women as many 138 people with purposif sampling technique. Data collection were managed by using questionnaire. Data analysis used chi-square statistic test. The result test show a influence between mother motivation with of early cervix cancer detection through inspection of visual acid acetate (IVA) with p-value 0,043 ( $\alpha \leq 0,05)$. Ecpected to Comunity Healty Center to Improved knowledge of correct IVA examination procedures through the promotion of programmed and repeated health.
\end{abstract}

Keywords: Motivation, Inspection Of Visual Acid Acetate

\begin{abstract}
ABSTRAK
Kanker leher rahim menjadi suatu permasalahan kesehatan wanita yang perlu mendapat perhatian serius. Salah satu penyebabnya kematian akibat kanker serviks adalah keterlambatan deteksi. Data WHO tahun 2010, 500.000 kasus baru dengan kematian 280.000 penderita terjadi setiap tahun di seluruh dunia. Hal tersebut seharusnya dapat ditekan dengan melakukan upaya pencegahan primer melalui pemeriksaan IVA. Tujuan penelitian ini adalah untuk mengetahui hubungan motivasi ibu dengan deteksi dini kanker serviks melalui metode inspeksi visual asam asetat (IVA). Jenis penelitian ini menggunakan rancangan cross sectional. Penelitian ini dilakukan di Wilayah Kerja Puskesmas Kebun Sikolos pada bulan Maret 2018. Sampel penelitian adalah wanita usia subur sebanyak 138 orang dengan teknik Purposif Sampling. Teknik pengumpulan data menggunakan kuesioner. Teknik analisis data menggunakan uji statistik Chi Square. Hasil penelitian menunjukkan bahwa ada hubungan motivasi ibu dengan deteksi dini kanker serviks melalui metode inspeksi visual asam asetat (IVA) dengan p-value 0,043 $(\alpha \leq 0,05)$. Diharapkan untuk Puskesmas Kebun Sikolos untuk dapat meningkatan pengetahuan tentang prosedur pemeriksaan IVA yang benar melalui promosi kesehatan yang terprogram dan berulang.
\end{abstract}

Kata Kunci: Motivasi , Metode IVA

Hubungan Motivasi Ibu dengan Deteksi Dini Kanker Serviks Melalui Metode Inspeksi Visual Asam Asetat (IVA) - | 45

Weni Lidya Hendayani, Hendrawati 


\section{PENDAHULUAN}

Wanita menempati peran utama dalam sebuah keluarga, demikian juga kesehatan yang berperan utama dalam sebuah kehidupan seseorang. Kesehatan adalah suatu hal yang harus diupayakan dan dijaga sehingga dapat tercapai kualitas hidup yang baik. Kesehatan reproduksi adalah bidang kesehatan yang khusus mempelajari hal-hal yang berkaitan dengan kandungan seorang wanita salah satunya adalah tumor dan kanker (Samadi, 2010).

Insiden kanker leher rahim sebenarnya dapat ditekan dengan melakukan upaya pencegahan primer seperti meningkatkan atau intensifikasi kegiatan penyuluhan kepada masyarakat untuk menjalankan pola hidup sehat, menghindari faktor risiko terkena kanker, melakukan immunisasi dengan vaksin HumanPapillomavirus (HPV) dan diikuti dengan deteksi dini kanker leher rahim tersebut melalui pemeriksaan pap smear atau inspeksi visual dengan menggunakan asam asetat (IVA) (Sabrina, 2015).

Deteksi dini kanker leher rahim di Indonesia melalui papsmear dan IVA masih sangat rendah (sekitar 5\%), padahal cakupan deteksi dini yang efektif dalam menurunkan angka kesakitan dan angka kematian karena kanker leher rahim adalah (85\%) (Saslow et al, 2012).

Beberapa faktor hambatan pemeriksaan pap smear diantaranya adalah perilaku wanita usia subur yang enggan untuk diperiksa karena kurangnya pengetahuan wanita pasangan usia subur tentang pap smear rasa malu dan rasa takut untuk memeriksa organ reproduksi kepada tenaga kesehatan, faktor biaya khususnya pada golongan ekonomi lemah, sumber informasi dan fasilitas atau pelayanan kesehatan yang masih minim untuk melakukan pemeriksaan pap smear (Schiffman \& Solomon, 2013). Pada golongan ekonomi lemah, sumber informasi dan fasilitas atau pelayanan kesehatan yang masih minim untuk melakukan pemeriksaan pap smear (Schiffman \& Solomon, 2013).

Deteksi dini kanker serviks yang dikenal umum adalah pap smear, yang biasanya dilakukan di rumah sakit di bagian laboratorium. Namun, ada pula cara alternative yakni metode IVA.IVA merupakan pemeriksaan dengan cara mengamati secara inspekulo serviks yang telah dipulas dengan asam asetat atau asam cuka (3-5\%) selama 1 menit. 
Daerah yang tidak normal akan berubah warna dengan batas tegas yang menjadi putih acetowhite, yang mengindikasikan bahwa serviks mungkin memiliki lesi pra kanker. Program pemeriksaan atau skrining yang ideal dan optimal untuk kanker serviks menurut WHO, sangat dianjurkan pada setiap wanita dan dilakukan setiap 3 tahun pada usia 25 60 tahun. Metode ini sudah banyak digunakan di Puskesmas, BPS, ataupun di Rumah Sakit. Metode inspeksi lebih mudah, lebih sederhana sehingga skrining dapat dilakukan dengan cakupan lebih luas dan diharapkan temuan kanker serviks dini akan bisa lebih banyak (Samadi, 2010).

Menurut Organisasi Kesehatan Dunia atau WHO (World Health Organization), terdapat insiden kanker serviks baru 493.243 jiwa per tahun, dengan angka kematian sebanyak 273.505 jiwa per tahun (Emilia, 2010). Kanker serviks merupakan kanker nomor dua terbanyak pada wanita umur 15-45 tahun setelah kanker payudara, tidak kurang dari 500.000 kasus baru dengan kematian 280.000 penderita terjadi setiap tahun di seluruh dunia. Hal ini bisa dikatakan setiap dua menit seorang wanita meninggal akibat kanker serviks. Indonesia merupakan salah satu negara dengan jumlah penderita kanker serviks yang tinggi di dunia. Setiap 1 menit muncul 1 kasus baru dan setiap 2 menit meninggal 1 orang wanita karena kanker serviks. Diperkirakan setiap hari muncul 40-45 kasus baru, 20-25 orang meninggal, berarti setiap jam diperkirakan 1 orang wanita meninggal dunia karena kanker serviks. Artinya Indonesia akan kehilangan 600-750 orang wanita produktif tiap bulannya (Puspita, 2015).

Menurut Kementerian Kesehatan Republik Indonesia, di Indonesia kanker serviks menempati urutan kedua dari semua jenis kanker pada wanita, dengan insiden kanker serviks adalah 100 per 100.000 penduduk per tahun (Savitri, 2015).

Menurut Pusat Data dan Informasi Kesehatan (2015), IVA merupakan program yang sedang digalangkan dalam Menurut Kementerian Kesehatan Republik Indonesia, di Indonesia kanker serviks menempati urutan kedua dari semua jenis kanker pada wanita, dengan insiden kanker serviks adalah 100 per 
100.000 penduduk per tahun (Savitri, 2015).

Kegiatan deteksi dini dilaksanakan di Puskesmas dengan rujukan ke Rumah Sakit Kabupaten/Kota dan Rumah Sakit Tingkat Provinsi. Kegiatan pokoknya adalah advokasi dan sosialisasi, pelatihan (training of trainers), pelatihan provider di Kabupaten/Kota, pelatihan kader di Puskesmas, promosi, pelaksanaan skrining, pencatatan dan pelaporan (surveilans), serta monitoring dan evaluasi (Kemenkes RI, 2015).

Prevalensi Penderita kanker serviks di Provinsi Sumatera Barat pada tahun 2013 adalah 170 per 100.000 penduduk. Menurut Yayasan Kanker Indonesia (YKI), Sumatera Barat merupakan provinsi kedua dengan jumlah kanker serviks tertinggi, yaitu 82 per 100.000 penduduk, dengan daerah Padang dan Solok sebagai penyumbang terbanyak. Peningkatan kasus ini terlihat dari tahun 2007 sebanyak 36 kasus sampai tahun 2013 dengan 42 kasus.

Prevalensi penderita kanker serviks di kota Padang Panjang menduduki peringkat ke 7 di Sumatera Barat. Berbagai cara telah dilakukan di berbagai daerah, untuk mengajak masyarakat agar mengetahui, dan mendeteksi dini kanker serviks, termasuk dikota Padang Panjang, yang mana pada tanggal 21 April 2017 telah dilakukan pemeriksaan IVA di UPTD Puskesmas Bukit Surungan yang mana wanita usia subur yang telah melakukan pemeriksaan IVA sebanyak 164 orang .

Saat ini pemeriksaan IVA dapat dilakukan di pusat-pusat pelayanan kesehatan seperti Rumah Sakit dan Puskesmas.

Untuk pemeriksaan IVA deteksi dini kanker serviks dapat dipengaruhi oleh beberapa faktor seperti faktor internal (dari dalam dirinya sendiri), yaitu pengetahuan dan motivasi. Motivasi dapat diartikan sebagai suatu keinginan yang terdapat dalam diri seseorang individu yang mendorongnya untuk melakukan perbuatan-perbuatan, tindakan, tingkah laku atau perilaku (Notoatmojo, 2009).

Motivasi sangat berhubungan erat dengan bagaimana perilaku itu dimulai, dikosongkan,dikuatkan,diarahkan,dihenti kan dan reaksi subjektifitas macam apakah yang timbul dalam organisasi ketika semua berlangsung. Motivasi merupakan keinginan untuk melakukan 
sesuatu dan menentukan kemampuan bertindak untuk memuaskan kebutuhan individu (Robbins, 2008).

Berdasarakan data yang didapatkan jumlah perempuan usia subur sePuskesmas Kota Padang Panjang yaitu 76.687 orang. Yang terdiri dari Kebun Sikolos yaitu 1856 orang, Bukit Surungan 1848 orang, Koto Katiak 1727 orang dan Puskesmas Gunung sebanyak 1256 orang. Dari data diatas perempuan usia subur yang melakukan pemeriksaan IVA yang sedikit berada di kebun Sikolos dengan jumlah wanita yang melakukan pemeriksaan sebanyak 142 orang, yang terdiri dari 4 wilayah kerja yaitu Pasar Baru 37 orang, Tanah Hitam 34 orang, Balai-balai 35 orang dan Kampung Manggis 36 orang.

Dari data diatas perempuan usia subur di Kebun Sikolos banyak tetapi yang melakukan pemeriksaan IVA hanya sedikit yaitu (2\%) dari jumlah perempuan usia subur. Kemudian peneliti melakukan wawancara dengan seorang perawat, perempuan usia subur tidak melakukan pemeriksaan IVA karena motivasinya kurang dan tidak ada motivasi dari keluarganya dan juga mereka takut karena benda asing masuk kedalam tubuhnya.
Dan juga wawancara dengan seorang responden dia melakukan pemeriksaan IVA alasannya karena saat berhubungan organ intimnya terasa sakit dan keluar bercak darah.

Berdasarkan hasil data dan wawancara dengan perawat dan seorang responden diatas peneliti tertarik melakukan penelitian tentang "Hubungan Motivasi Ibu dengan Deteksi Dini Kanker Servik melalui Metode Inspeksi Visual Asam Asetat (IVA) di Wilayah Kerja Kebun Sikolos".

\section{METODOLOGI}

Metode penelitian yang digunakan dalam penelitian ini adalah deskriptif korelasional dengan menggunakan metode penelitian deskriptif. Tujuan utama dalam menggunakan metode ini adalah untuk mengambarkan sifat suatu keadaan yang sementara berjalan pada saat penelitian dilakukan dan memeriksa sebab-sebab dari suatu gejala tertentu.

Penelitian ini dilaksanakan di Puskesmas Kebun Sikolos pada bulan September 2018.

Peneliti melakukan wawancara dengan seorang perawat, yang menyatakan bahwa perempuan usia subur tidak melakukan pemeriksaan IVA karena 
motivasinya kurang dan tidak ada motivasi dari keluarga nya dan juga mereka takut karena benda asing masuk kedalam tubuhnya. Dan wawancara dengan salah seorang pasien yang telah melakukan pemeriksaan IVA dia mengatakan bahwa pemeriksaan IVA sangat penting, karena dengan pemeriksaaan IVA kita dapat mengetahui apakah kita terkena kanker serviks atau tidak, dan sebelum dia melakukan pemeriksaan IVA dia mengatakan bahwa saat berhubungan intim terasa sakit pada daerah intim dan keluar bercak darah.

Setelah melakukan survey awal peneliti membuat proposal tentang Hubungan Motivasi Ibu dengan Deteksi Dini Kanker Serviks Melalui Metode Inspeksi Visual Asam Asetat (IVA)..

Selanjutnya peneliti pergi mengunjungi rumah masing - masing masyarakat yang akan dijadikan sampel dalam penelitian untuk melakukan penelitian tersebut. Pengumpulan data dilaksanakan dengan memberikan kuesioner kepada ibu yang terlebih dahulu menjelaskan surat persetujuan penelitian dan cara pengisian kuesioner. Setelah disetujui responden dan menandatangani surat persetujuan, kemudian dilakukan pengambilan data. Selama pengisian kuesioner penelitian berada didekat responden, sambil mewawancara responden, setelah pengisian kuesioner tersebut dikumpulkan dan diperiksa kelengkapan oleh peneliti.

Penelitian dilakukan selama sebulan. Setelah semua data terkumpul, barulah peneliti melakukan pengolahan data dengan komputerisasi yaitu dengan menggunakan metode SPSS (Statistical Package for the Sosial Sciences).

Diterima apabila $p \leq 0,05$, berarti ada hubungan yang signifikan antara motivasi ibu dengan deteksi dini kanker serviks melalui metode inspeksi visual asam asetat (IVA) di Puskesmas Kebun Sikolos Padang Panjang.

\section{HASIL DAN PEMBAHASAN}

Berdasarkan karakteristik responden dilihat dari tingkat pendidikan yang menyatakan setuju dengan deteksi dini kanker serviks melalui metode inspeksi visual asam asetat (IVA) adalah yang berpendidikan SMA. 
Tabel 1. Distribusi Frekuensi Motivasi Ibu

\begin{tabular}{cccc}
\hline No & $\begin{array}{c}\text { Motivasi } \\
\text { Ibu }\end{array}$ & Jumlah & $\begin{array}{c}\text { Presentase } \\
\%\end{array}$ \\
\hline 1 & Kuat & 1 & 0.7 \\
2 & Sedang & 137 & 99.3 \\
3 & Lemah & 0 & 0 \\
\hline & Jumlah & $\mathbf{1 3 8}$ & $\mathbf{1 0 0 , 0}$ \\
\hline
\end{tabular}

Berdasarkan tabel diatas diketahui bahwa hampir seluruh responden mempunyai motivasi yang sedang yaitu sebanyak 137 orang (99.3\%).Berdasarkan kuesioner yang dibagikan berdasarkan pernyataan pemeriksaan kanker serviks sebaiknya dilakukan 1 kali sepanjang usia saya, sebagian responden menjawab raguragu dan sebagian responden menjawab sangat tidak setuju.

Tabel 2. Distribusi Frekuensi Deteksi Dini Kanker Serviks melalui Metode Visual Asam Asetat (IVA)

\begin{tabular}{clcc} 
No & Deteksi Dini (DDKS) & Jumlah & Presentase \% \\
\hline 1 & Ya Melakukan & 6 & 4.3 \\
2 & Tidak Melakukan & 132 & 95.7 \\
\hline & Jumlah & $\mathbf{1 3 8}$ & $\mathbf{1 0 0 , 0}$ \\
\hline
\end{tabular}

Dari tabel di atas diketahui hasil analisis hubungan antara motivasi ibu dengan deteksi dini kanker serviks melalui metode inspeksi visual asam asetat (IVA) diperoleh ibu yang motivasinya sedang ada 132 orang (96.4\%) yang tidak melakukan deteksi dini kanker serviks melalui metode inspeksi visual asam asetat (IVA).

Dari hasil analisis diperoleh nilai OR = 27.4,yang artinya ibu yang motivasinya sedang mempunyai peluang 27.4 kali untuk tidak melakukan deteksi dini kanker serviks melalui metode inspeksi visual asam asetat (IVA).

Berdasarkan hasil uji statistik menunjukkan bahwa terdapat hubungan yang signifikan motivasi ibu dengan deteksi dini kanker serviks melalui metode inspeksi visual asam asetat (IVA) di Wilayah Kerja Puskemas Kebun Sikolos Padang Panjang, tahun 2018, ditandai dengan nilai p $0,043<\alpha(0,05)$, yang artinya $\mathrm{H}_{0}$ ditolak. 
Tabel 3. Hubungan Motivasi Ibu Dengan Deteksi Dini Kanker Serviks Melalui Metode Inspeksi Visual Asam Asetat (IVA)

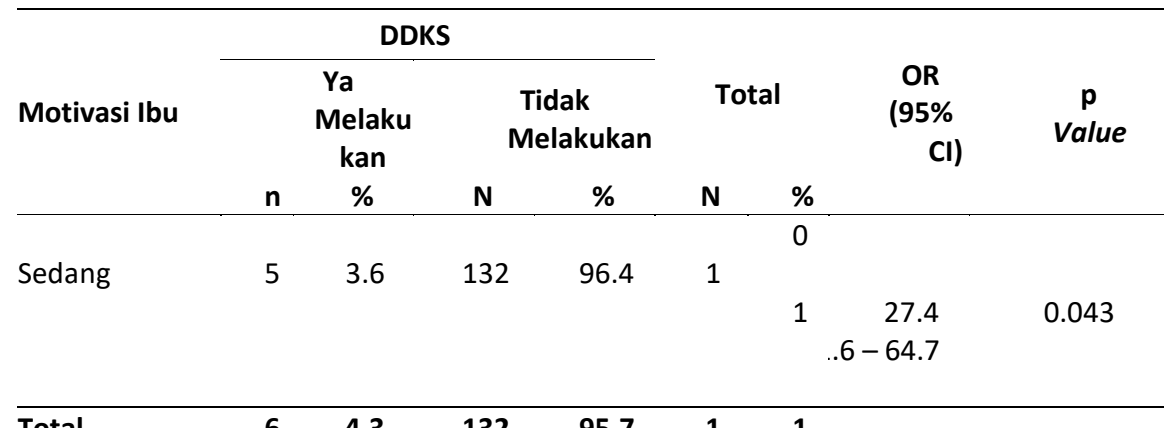

Berdasarkan tabel di atas diketahui hasil analisis hubungan antara motivasi ibu dengan deteksi dini kanker serviks melalui metode inspeksi visual asam asetat (IVA) diperoleh ibu yang motivasinya sedang ada 132 orang (96.4\%) yang tidak melakukan deteksi dini kanker serviks melalui metode inspeksi visual asam asetat (IVA).

Dari hasil analisis diperoleh nilai $\mathrm{OR}=$ 27.4,yang artinya ibu yang motivasinya sedang mempunyai peluang $27.4 \mathrm{kali}$ untuk tidak melakukan deteksi dini kanker serviks melalui metode inspeksi visual asam asetat (IVA).

Berdasarkan hasil uji statistik menunjukkan bahwa terdapat hubungan yang signifikan motivasi ibu dengan deteksi dini kanker serviks melalui metode inspeksi visual asam asetat (IVA) di Wilayah Kerja Puskemas Kebun Sikolos Padang Panjang, tahun 2018, ditandai dengan nilai $\mathrm{p} 0,043<\alpha(0,05)$, yang artinya $\mathrm{H}_{0}$ ditolak.

Berdasarkan tabel di atas, diketahui bahwa hampir seluruh responden mempunyai motivasi yang sedang yaitu sebanyak $99.3 \%$, hanya $0.7 \%$ ibu yang mempunyai motivasi kuat di wilayah kerja Puskesmas Kebun Sikolos, Padang Pajang, tahun 2018.

Menurut Uno, Motivasi dapat diartikan sebagai kekuatan yang terdapat dalam diri individu, yang menyebabkan individu tersebut bertindak atau berbuat. Motivasi merupakan dorongan yang terdapat dalam diri seseorang untuk berusaha mengadakan perubahan tingkah laku yang lebih baik dalam memenuhi kebutuhannya. Motivasi terjadi apabila 
seseorang mempunyai keinginan dan kemauan untuk melakukan suatu kegiatan atau tindakan dalam rangka mencapai tujuan tertentu (Uno, 2007).

Menurut Sutrisno motivasi adalah "faktor yang mendorong seseorang untuk melakukan suatu aktivitas tertentu, motivasi sering kali diartikan pula sebagai faktor pendorong perilaku seseorang" (Sutrisno 2013).

Menurut penelitian $\begin{array}{r}\text { yang } \\ \text { (2016), }\end{array}$
dilakukan oleh Lisnawati
mengatakan bahwa responden yang
pernah mengikuti tes IVA mayoritas
mempunyai minat yang tinggi untuk
mengikuti tes IVA lagi yaitu sebanyak 10
orang (25.0\%) dan tidak ada yang
mempunyai minat yang
rendah.Sedangkan untuk responden yang tidak pernah melakukan tes IVA mayoritas juga memiliki minat yang tinggi untuk mengiikuti tes IVA yaitu sebanyak 25 orang $(62.5 \%)$ dan minoritas mempunyai minat yang rendah sebanyak 1 orang $(2.5 \%)$. Rendahnya keikutsertaan masyarakat dalam mengikuti tes IVA pada penelitian ini sedikit pengaruhnya dengan tingkat pengetahuan dan minat yang dimiliki oleh ibu, mayoritas ibu mempunyai kesadaran masing-masing akan pentingnya mengikuti tes tersebut tetapi keikutsertaanya dalam tes IVA sangat rendah hal ini terjadi dikarenakan ada faktor lain yang menyebabkan ibu tidak mau melakukan tes IVA.

Sedangkan penelitian yang dilakukan oleh Hartati (2016), mengatakan bahawa sebagian besar responden yaitu sebanyak 29 orang $(52,7 \%)$ memiliki tingkat motivasi sedang dan sebanyak 20 orang $(36,4 \%)$ memiliki motivasi tinggi dan ada sebanyak 6 orang $(10,9 \%)$ yang memiliki motivasi rendah.

Menurut Sari (2017), dalam penelitiannya yaitu Hubungan Motivasi Deteksi Dini Kanker Serviks dengan Tindakan Pap Smear Pada Wanita Usia Subur dengan hasil penelitian menunjukkan bahwa mayoritas motivasi wanita usia subur untuk melakukan deteksi dini kanker serviks adalah rendah yaitu sebesar 30 orang $(60,0 \%)$.

Menurut penelitian yang dilakukan oleh Nigrum (2013) dapat diketahui bahwa motivasi ibu mengikuti deteksi dini kanker serviks melalui metode Inspeksi Visual Asam Asetat (IVA) di Kabupaten Banyumas Tahun 2012 paling banyak termasuk kategori tinggi sebanyak 47 orang $(49,5 \%)$ 
sedangkan paling sedikit termasuk kategori rendah sebanyak 6 orang $(6,3 \%)$. Menurut penelitian yang dilakukan oleh Yevin (2017), hasil penelitian pada 55 resonden yang belum melakukan pemeriksaan IVA, diperoleh bahwa sebanyak 20 responden (36\%) belum melakukan pemeriksaan IVA dikarenakan takut, 6 responden (11\%) dikarenakan malu dan 29 respondon (53\%) menyatakan bahwa tidak tahu mengenai pemeriksaan IVA. Alasan takut yang menyebabkan 20 responden memutuskan untuk tidak memeriksakan deteksi dini kanker servik adalah 100\% takut dengan prosedur pemeriksaan.

Sedangkan menurut peneliti motivasi disini adalah rasa keinginan atau dorongan yang tumbuh dalam diri seorang ibu untuk melakukan deteksi dini kanker serviks, yang disebabkan oleh pengetahuan ibu akan resiko yang akan ditimbulkan apabila kanker serviks ini terlambat diketahui.

Menurut peneliti agar seorang ibu mempunyai motivasi untuk melakukan pemeriksaan IVA di sarankan kepada pelayanan kesehatan agar lebih meoptimalkan lagi penyuluhan atau informasi yang berkaitan tentang kanker serviks dan metode IVA . Baik kepada ibu, suami maupun kepada anggota keluarga lainnya.

\section{Deteksi Dini Kanker Serviks melalui Metode Visual Asam Asetat (IVA)}

Berdasarkan tabel di atas
responden tidak melakukan deteksi dini kanker serviks melalui metode visual asam asetat (IVA) yaitu (95.7\%), hanya $(4.3 \%$ ) ibu yang ada melakukan deteksi dini kanker serviks melalui metode visual asam asetat (IVA) di wilayah kerja Puskesmas Kebun Sikolos Padang Panjang, tahun 2018.

Menurut Rasjidi deteksi dini kanker adalah usaha untuk mengidentifikasi penyakit atau kelainan yang secara klinis belum jelas dengan menggunakan tes, pemeriksaan, atau prosedur tertentu yang dapat digunakan secara tepat untuk membedakan orangorang yang kelihatannya sehat, benarbenar sehat dengan tampak sehat tetapi sesungguhnya menderita kelainan (Rasjidi, 2009).

Menurut Nurcahyo, IVA adalah cara yang mudah dan murah dapat dilakukan oleh bidan atautenaga medis, puskesmas, prinsip kerja puskesmas ini 
adalah dengan mengolesi mulut rahim dengan asam asetat. kondisi kesamaan lendir dipermukaan mulut rahim yang telah terinfeksi oleh sel prakanker akan berubah warna menjadi putih melalui bantuan cahaya, petugas medis akan melihat bercak putih pada mulut raim (Nurcahyo, 2010).

Penelitian ini juga dilakukan oleh Yevin (2017), hasil penelitian kepada 100 responden di 10 desa terpilih didapatkan hasil bahwa, 45 responden (45\%) telah melakukan pemeriksaan IVA, 55 responden $(55 \%)$ belum melakukan pemeriksaan IVA. Alasan belum melakukan pemeriksaan IVA sebanyak (53\%) dikarenakan tidak tahu mengenai deteksi dini kanker servik metode IVA dan yang kedua adalah karena rasa takut (35\%) atau 20 responden.

Sedangkan menurut Farizal (2017), mengatakan bahwa responden belum pernah melakukan tindakan pemeriksaan IVA sebanyak (41,3\%) dan yang sudah melakukan tindakan pemeriksaan IVA sebanyak (58,7\%). Dengan demikian bahwa responden sebagian besar sudah pernah melakukan tindakan pemeriksaan IVA.demikian bahwa responden sebagian besar sudah pernah melakukan tindakan pemeriksaan IVA.

Sedangkan menurut peneliti Deteksi Dini kanker Serviks melalui metode visual asam asetat (IVA) adalah pemeriksaan leher rahim yang biasa dilihat dengan mata telanjang dengan cara menggunakan asam cuka (3-5\%) sehingga bisa mendeteksi jika ada kelainan atau gejala yang tidak normal pada serviks.

Penyebab yang menjadi faktor penghambat pada wanita dalam melakukan deteksi dini kanker serviks adalah keraguan akan pentingnya pemeriksaan, kurang pengetahuan, dan takut akan rasa sakit serta keengganan karena malu saat dilakukannya pemeriksaan.

Rendahnya pengetahuan perempuan tentang kanker serviks membuat rendahnya keinginan untuk melakukan deteksi dini, hal itu disebabkan karena masih awam dengan Metode Inpseksi Visual Asam Asetat untuk mengetahui kanker serviks.

Menurut peneliti dilihat dari kuesioner yang telah di sebar tentang pernyataan pemeriksaan dini kanker serviks penting untuk wanita seusia saya 
dan pernyataan pemeriksaan kanker serviks dengan tes IVA diperlukan untuk seluruh wanita yang telah menikah, hampir seluruh responden mengatakan setuju dan mengatakan sangat setuju untuk melakukan pemeriksaan IVA.

Berdasarkan tabel di atas diketahui hasil analisis hubungan antara motivasi ibu dengan deteksi dini kanker serviks melalui metode inspeksi visual asam asetat (IVA) diperoleh keseluruhan (100\%) ibu yang motivasinya kuat, ada melakukan deteksi dini kanker serviks melalui metode inspeksi visual asam asetat (IVA). Sedangkan ibu yang motivasinya sedang ada (96.4\%) yang tidak melakukan deteksi dini kanker serviks melalui metode inspeksi visual asam asetat (IVA).

Berdasarkan hasil uji statistik menunjukkan bahwa terdapat hubungan yang signifikan motivasi ibu dengan deteksi dini kanker serviks melalui metode inspeksi visual asam asetat (IVA) di Wilayah Kerja Puskemas Kebun Sikolos Padang Panjang, tahun 2018, ditandai dengan nilai $p 0,043<\alpha(0,05)$, yang artinya $\mathrm{H}_{0}$ ditolak.

Menurut Saputri (2016) mengatakan hasil uji analisis Chi-Square, penelitian diperoleh nilai $p=0,001<\alpha=$ 0,05 sehingga terdapat hubungan antara tingkat pengetahuan tentang Test Inspeksi Visual Asam Asetat dengan keikutsertaan wanita dalam melakukan pemeriksaannya di Desa Godegan Mojolaban Sukoharjo.

Menurut peneliti hubungan motivasi ibu dengan deteksi dini kanker serviks melalui metode inspeksi visual asam asetat (IVA) sangatlah erat sekali, ibu dengan usia produktif jika mengetahui bahaya kanker serviks akan melakukan pemeriksaan secara dini, namun dalam penelitian ini sebagian besar ibu motivasinya sedang sehingga banyak yang tidak melakukan deteksi dini kanker serviks, ini disebabkan karena informasi yang diterima oleh para ibu tentang deteksi dini kanker serviks melalui metode inspeksi visual asam asetat (IVA) tidak cukup banyak dan masih menjadi hal baru di kalangan masyarakat sehingga motivasi mereka banyak yang sedang-sedang saja.

Kurangnya motivasi wanita subur terhadap pelaksanaan metode IVA Disebabkan karena mereka beranggapan untuk apa melakukan IVA pada hal meraka tidak pernah berganti-ganti pasangan dan meerokok serta usia ketika 
menikah tergolong usia produktif maka tidak mungkin terkena kanker serviks.

Kurangnya informasi dan penyuluhan kesehatan mmengenai kanker serviks juga merupakan faktor penyebab rendahnya wanita subur dalam melakukan metode IVA ini, karena masyarkat tidak mengetahui apa bahaya dari kanker serviks dan akibat lanjut yang timbul ketika terkena kanker serviks.

Maka dari itu disarankan kepada lembaga kesehatan agar lebih meoptimalkan lagi tentang penyuluhan dan informasi yang berkaitan dengan kanker serviks dan metode IVA, seperti memasang poster tentang kanker serviks dan metode IVA, di berbagai lembaga kesehatan.

\section{KESIMPULAN}

Berdasarkan hasil penelitian yang telah dilakukan maka dapat ditarik kesimpulan bahwa dari hasil uji statistik didapatkan bahwa hampir seluruh responden mempunyai motivasi yang sedang yaitu sebanyak (99.3\%), hanya $(0.7 \%)$ ibu yang mempunyai motivasi kuat, hampir seluruh responden tidak melakukan deteksi dini kanker serviks melalui metode visual asam asetat (IVA) yaitu $(95.7 \%)$, hanya $(4.3 \%)$ ibu yang ada melakukan deteksi dini kanker serviks melalui metode visual asam asetat (IVA).

Terdapat hubungan yang signifikan motivasi ibu dengan deteksi dini kanker serviks melalui metode inspeksi visual asam asetat (IVA) di Wilayah Kerja Puskemas Kebun Sikolos Padang Panjang, tahun 2018, ditandai dengan nilai $p 0,043<\alpha(0,05)$, yang artinya $\mathrm{H}_{0}$ ditolak dengan nilai $\mathrm{OR}=27.4$,yang artinya ibu yang motivasinya sedang mempunyai peluang 27.4 kali untuk tidak melakukan deteksi dini kanker serviks melalui metode inspeksi visual asam asetat (IVA).

\section{REKOMENDASI}

Disarankan kepada pemerintah atau dinas terkait untuk mengharuskan seluruh wanita usia subur dan baru menikah melakukan deteksi dini kanker serviks melalui metode visual asam asetat (IVA).

\section{DAFTAR PUSTAKA}
A.Alimul Hidayat. (2007) . Metode Penelitian Kebidanan Dan Tehnik Analisis Data.Surabaya : Salemba.

Arikunto, Suharsimi. (2010). Prosedur Penelitian Suatu Pendekatan 
Praktik.Yogyakarta:Bina

Aksara.

Azwar, S. (2005). Sikap manusia teori dan pengukurannya Yogyakarta : Pustaka Pelajar Offset.

B. Uno, Hamzah. (2007). Teori Motivasi dan Pengukurannya. Jakarta : Bumi Aksana.

Brida Kity Dinarum Vina Walnoyevin. (2017) Faktor- Faktor Yang Berhubungan Dengan Pemeriksaan Deteksi Dini Kanker Serviks Metode Inspeksi Visual Asam (IVA) Di Wilayah Kerja Puskesmas Buayan Kebumen. Program Studi Bidan Pendidik Jenjang Diploma IV Fakultas Ilmu Kesehatan Universitas 'Aisyiyah: Yogyakarta.

Depkes RI. (2010). Profil Kesehatan Indonesia 2008. Available from: http://www.depkes.go.as retrieved on 25 November 2017: 09:00 PM.

Emilia, O, dk. (2010). Bebas Ancaman Kanker Serviks (Fakta, Pencegahan, dan Penanganan Dini terhadap Serangan Kanker Serviks).Yogyakarta : : Media Pressindo.

Emilia, O., Yudha, P.H., Kusumanto, D., Freitag, H. (2010). Bebas Ancaman Kanker Serviks. Yogyakarta: Medpress Jakarta : Bumi Aksana.

Farizaal Desta Hafidz. (2017) Hubungan Tingkat Pengetahuan Pasangan
Usia Subur (PUS) Tentang Kanker Serviks Dengan Tindakan Pemeriksaan Inspeksi Visual Asam Asetat (IVA) Di Puskesmas Selomerto Kabupaten Wonosobo. Program Studi Pendidikan Dokter Fakultas Kedokteran Universitas Muhammadiyah: Surakarta.

Hidayat.A. (2007) .Metode Penelitian Keperawatan dan Tekhnik Analisa Data. Jakarta : Salemba Medika.

Kementerian Kesehatan RI. (2015). Buletin Jendela Data \& Informasi Kesehatan, Semester 1, 2015 : Jakarta.

Buletin Jendela Data \& Informasi Kesehatan : Jakarta.

Kusttiyati Sri, Winarni. (2012). Deteksi Dini Kanker Leher Rahim Dengan Metode IVA di Wilayah Kerja PuskesmaS Ngoresan Surakarta, GASTER, Vol. 8, No. 1 Februari 2011 (681-694).

Deteksi Dini \& Pencegahan Kanker pada Wanita. Jakarta : Sagung Seto.

McClelland, D.C. (2005). The Achieving Society. New Jersey : Van Nostrand Reinhold.

Notoatmodjo. (2010). Metodologi Penelitian Kesehatan. Jakarta : PT. Rineka Cipta.

Puspita, S.A. (2015). Stop Kanker Serviks. Yogyakarta: Notebook. 
Rasjidi, Imam. (2008). Manual Prakanker Serviks. Jakarta : CV AgungSeto.

Robbins, Stephen P, Timothy A. Judge. (2008). Perilaku Organisasi. Jakarta: Salemba Empat.

Sabrina, Setiawati, Wahidin. (2015). Situasi Penyakit Kanker.. Data dan Informasi Kesehatan. Jakarta.

Samadi,P. (2010). Yes, I Know Everything About Kanker Serviks : Jakarta . Tiga Kelana.

Sankaranarayanan R., Budukh AM., Rajkumar R.. (2001). Effective Screening programmes for cervical cancer in low and middle-income developing countries. Bull WHO;79:95462.

Saputi, Ayu Mentari. (2016) Hubungan Tingkat Pengetahuan Tentang Test Inspeksi Visual Asam Asetat ( IVA ) Dengan Keikutsertaan Wanita Dalam Melakukan Pemeriksaannya Di Desa Godegan Mojolaban Sukoharjo. Fakultas Ilmu Kesehatan Universitas Muhammadiyah: Surakarta.

Saslow,Et.al. (2012). American Cancer Society, American Society for coloscopy and society for clinical pathology screenly guidelines for the preventor and early detection of cervical cancer. National Institutes of health. CA Cancer J Clin.
Savitri, A. (2015). Kupas Tuntas Kanker Payudara \& Kanker Leher Rahim. Yogyakarta : Pustaka Baru Press.

Schiffman \& Solomon. (2013). Servical Cancer Screamy with Homan Papilloma virus and Cytolocig Cotesting. The New England Journal Of Medicine.

Sugiyono. (2010) .Metode Penelitian Kuantitatif dan R\&D. Bandung : Alfabeta

Sugiyono. (2010). Metode Penelitian Kualitatif dan kuantitatifDan $R$ $\& D$, Bandung : ALFA BETA.

Suwiyoga, I Ketut. (2001). Beberapa Masalah Pap Smear Sebagai Alat Diagnosis Dini Karakter Serviks Di Indonesia. Available from http:/lejournal.unud. ac.id as retrieved on 24 Oktober 2017 : 11:00 AM.

Wahyuni, Sri. (2013). Faktor -Faktor Yang Mempengaruhi Perilaku Deteksi Dini Kanker Serviks Dikecamatan Ngampel Kabupaten Kendal Jawa Tengah. Diakses Melalui http:// http://scholar.google.co.id/. Pada tanggal 18 November 2017.

Wahyuningsih, T., Yudhya, E.M. (2014). Faktor Risiko Terjadinya Lesi Prakanker Serviks Melalui Deteksi Dini dengan Metode IVA (Inspeksi Visual Asam Asetat). Jakarta : Forum Ilmiah, Volume 11 No.2, Mei 2014. 
Wijaya, D. (2010). Pembunuh Ganas Itu Bernama Kanker Serviks. Yogyakarta: Sinar Kejora.

Wiknjosastro Hanifa. (2007). Ilmu Kandungan. Jakarta: Yayasan Bina Pustaka Sarwono Prawirohardjo.

Wlnoyevin Vina Dinarum Kity Brida. (2017) Faktor- faktor Yang Berhubungan Dengan Pemeriksaan Deteksi Dini Kanker Serviks Metode Inspeksi Visual Asam Asetat (IVA) Di Wilayah Kerja Puskesmas Buayan Kebumen. Program Studi Bidan Pendidik Jenjang Diploma IV Fakultas Ilmu Kesehatan Universitas 'Aisyiyah: Yogyakarta.

Yupiasari Beutifina. (2015) Faktor-faktor Yang Berhubungan Dengan Motivasi Pasangan Usia Subur Dalam Mengikuti Upaya Pencegahanca Serviks Melalui Metode Inspeksi Visual Asam Asetat (IVA) Di Puskesmas Sangkrah. Program Studi Kesehatan Masyarakat Fakultas Ilmu Kesehatanuniversitas Muhammadiyah: Surakarta. 